\title{
Comparing cytotoxicity of propoxur and Nepeta crispa (Lamiales: Lamiaceae) essential oil against invertebrate (Sf9) and vertebrate (L929) cell lines
}

\author{
Amirhossein Zahirnia ${ }^{1}$, Mitra Boroomand ${ }^{1}$, Hassan Nasirian ${ }^{2}$, Aref Salehzadeh ${ }^{1}$ and Sara Soleimani-Asl ${ }^{3}$
}

1. Department of Medical Entomology, School of Medicine, Hamadan University of Medical Sciences, Hamadan, Iran; 2. Department of Medical Entomology and Vector Control, School of Public Health, Tehran University of Medical Sciences, Tehran, Iran; 3. Department of Anatomy, School of Medicine, Hamadan University of Medical Sciences, Hamadan, Iran. Corresponding author: Aref Salehzadeh, e-mail: salehzadeh@umsha.ac.ir

Co-authors: AZ: zahirnia@umsha.ac.ir, MB: boroomand_mitra@yahoo.com,HN: hanasirian@yahoo.com, SS: sr_soleimani@yahoo.com

Received: 08-06-2019, Accepted: 30-09-2019, Published online: 04-11-2019

doi: www.doi.org/10.14202/vetworld.2019.1698-1706 How to cite this article: Zahirnia A, Boroomand M, Nasirian $H$, Salehzadeh A, Soleimani-Asl S (2019) Comparing cytotoxicity of propoxur and Nepeta crispa (Lamiales: Lamiaceae) essential oil against invertebrate (Sf9) and vertebrate (L929) cell lines, Veterinary World, 12(11): 1698-1706.

\begin{abstract}
Background and Aim: Attempts to use the plant products are to be an appropriate option due to substantial concerns about human health and environmental problems of using synthetic pesticides. Therefore, the cytotoxicity of Nepeta crispa essential oil was compared with propoxur against invertebrate (Sf9) and vertebrate (L929) cell lines.

Materials and Methods: The cell lines of Sf9 and L929 which were derived from the ovary glands of fall armyworm, Spodoptera frugiperda (Lepidoptera: Noctuidae) and mouse fibroblast cells, respectively, were obtained from the National Cell Bank of Pasteur Institute of Iran. About a number of $2 \times 10^{3}$ cells were placed into the wells of 96-well plate experiments. Then, appropriate concentrations of essential oil of $N$. crispa plant and propoxur added to the wells. The cells were allowed to grow for 3-5 days and estimated the numbers of cells. The cells of control experiment wells contained only cells with dimethyl sulfoxide. All control and treatment experiments repeated at least four replicates.
\end{abstract}

Results: Propoxur had negative effects on the viability of both invertebrate (Sf9) and vertebrate (L929) cell lines. The cytotoxicity of propoxur against invertebrate (Sf9) and vertebrate (L929) cell lines was gradually increased in accordance with propoxur concentrations. The cytotoxicity of $N$. crispa essential oil against vertebrate (L929) cell line was gradually decreased in accordance with plant concentrations, while the cytotoxicity of N. crispa essential oil against invertebrate (Sf9) cell line was strongly increased in accordance with plant concentrations.

Conclusion: Plant essential oil not only had no negative effects but also had boosting effects on vertebrate cell viability. Essential oil of $N$. crispa plant had negative effects on invertebrate cell viability with the differences that the products derived from plants possessing of biodegradable and environmentally friendly derivatives, hydrolyzing rapidly in nature, and nearly having no destructive effects on environment, humans, or the mammals.

Keywords: biodegradable derivative, invertebrate cell line, plant essential oil, plant natural products, vertebrate cell line.

\section{Introduction}

Attempts to use the plant products as natural pesticides usually based on plant essential oils are considered as a good candidate for the management of arthropod vectors of diseases and agricultural pests due to possessing of readily biodegradable and environmentally friendly derivatives [1-5]. There is a growing interest in the potential use of essential oils as a replacement for traditional herbicides and pesticides. Essential oils are complex natural products of plant origin exhibiting to have insecticidal, attractant, or repellent properties [6-8].

There are substantial concerns about human health and environmental problems of synthetic

Copyright: Zahirnia, et al. Open Access. This article is distributed under the terms of the Creative Commons Attribution 4.0 International License (http://creativecommons.org/licenses/ by/4.0/), which permits unrestricted use, distribution, and reproduction in any medium, provided you give appropriate credit to the original author(s) and the source, provide a link to the Creative Commons license, and indicate if changes were made. The Creative Commons Public Domain Dedication waiver (http:// creativecommons.org/publicdomain/zero/1.0/) applies to the data made available in this article, unless otherwise stated. pesticides. Pesticides have potential side effects despite their importance to public health. Exposures to various types of insecticides may be a risk factor for cancers. Several undesirable effects of pesticides are maybe toxicity to non-target organisms, residues of pesticides, depletion of ozone layer, environmental pollution, and direct toxicity to users [2,9-12]. Insecticide resistance in agricultural pests and vectors of diseases is also maybe as a substantial problem in management programs of the pests and vectors [7,13-19].

One of the most natural aromatic plants in Iran is Nepeta crispa Willd. (Lamiales: Lamiaceae) that is popular in Iranian traditional medicine, especially with Hamadan Province people. N. crispa have insecticidal activity with antimicrobial and antifungal properties. The N. crispa plants are autochthonous of Iran climate, especially Hamadan Province [20-22].

Many studies have been conducted on the insecticidal properties of $N$. crispa plant, but a simultaneous comparative study about the cytotoxicity of essential oil of $N$. crispa with synthetic pesticides 
such as propoxur against the cell lines of invertebrates and vertebrates would be a particular of importance. Therefore, in this study, we compared the cytotoxicity of $N$. crispa essential oil with propoxur against invertebrates and vertebrates cell lines.

\section{Materials and Methods}

\section{Ethical approval}

The study was approved by the Ethics Committee of Hamadan University of Medical Sciences, Hamadan, Iran, with approval number: IR.UMSHA. REC.1396.320.

\section{Invertebrate (Sf9) and vertebrate (L929) cell line providing}

Invertebrate (Sf9) and vertebrate (L929) cell lines were obtained from the National Cell Bank of Pasteur Institute of Iran. Cell line of Sf9 derived from the ovary glands of fall armyworm, Spodoptera frugiperda (Smith) (Lepidoptera: Noctuidae). Cell line of $\mathrm{Sf} 9$ is routinely cultured and maintained at $27^{\circ} \mathrm{C}$ in $5 \mathrm{ml}$ of Grace's insect cell culture medium in $25 \mathrm{~cm}^{2}$ culture flasks, enriched with $10 \%$ fetal bovine serum at Pasteur Institute of Iran. The doubling time of Sf9 cells was found to be 18-24 h under optimum conditions. Sf9 invertebrate cells were subcultured every 3 days. Cell line of L929 was derived from mouse fibroblast cells. It was maintained at $37^{\circ} \mathrm{C}$ in $3 \mathrm{ml}$ of Dulbecco's Modified Eagle Medium Media $\left(\right.$ Gibco $\left.^{\circledR}\right)$ in $25 \mathrm{~cm}^{2}$ culture flasks, enriched with $10 \%$ fetal bovine serum, and buffered with $4 \%$ sodium bicarbonate in an atmosphere of 5\% carbon dioxide. The doubling time of L929 cells for cultures was approximately $24 \mathrm{~h}$ and the cell was subcultured every 6 day [23].

\section{Plant essential oil isolation}

Technical grade of propoxur (white crystalline powder $97 \%$ ) was purchased from Guangdong Company, China (Mainland). The aerial parts (foliage) of $N$. crispa (Lamiales: Lamiaceae) during their flowering stage were collected from Avicenna Medicinal Herbs Research Center, Hamadan Province of Iran in June 2017. The plant was confirmed by a voucher specimen (no. 72) in the Department of Pharmacognosy, School of Pharmacy, Hamadan University of Medical Sciences, Hamadan, Iran. A total of 1000 g powder of shade-dried aerial parts of $N$. crispa were subjected to hydrodistillation using a Clevenger-type apparatus for $4 \mathrm{~h}$. The essential oil was dehydrated over anhydrous sodium sulfate and transferred into amber-colored vials to store in a refrigerator at $4{ }^{\circ} \mathrm{C}$ for further work.

\section{Bioassay procedures}

Essential oil $(0.1 \mathrm{mg})$ of $N$. crispa plant was dissolved with $1 \mathrm{ml}$ of dimethyl sulfoxide (DMSO) due to hydrophobic properties and then diluted with sterilized distilled water to prepare the concentrations of $10^{-10}, 10^{-9}, 10^{-8}, 10^{-7}, 10^{-6}, 10^{-5}, 10^{-4}$, and $10^{-3} \mathrm{ng} / \mu \mathrm{L}$ containing $0.00001,0.0001,0.001,0.01,0.1,1,10$, and $100 \mathrm{ng} / \mu \mathrm{L}$, respectively. Propoxur technical grade $(97 \%)$ was dissolved with ethanol $96 \%$ to prepare the concentrations of $10^{-10}, 10^{-9}, 10^{-8}, 10^{-7}, 10^{-6}, 10^{-5}, 10^{-4}$, and $10^{-3} \mu \mathrm{g} / \mu \mathrm{L}$ containing $0.000097,0.00097,0.0097$, $0.097,0.97,9.7,97$, and $970 \mu \mathrm{g} / \mu \mathrm{L}$, respectively.

To consider the cytotoxicity of essential oil of $N$. crispa plant and propoxur against invertebrate (Sf9) and vertebrate (L929) cell lines, about $2 \times 10^{3}$ cells $/ 100 \mu 1$ of culture medium were placed into the wells of a 96-well plate of treatment experiments and then appropriate concentrations of $N$. crispa essential oil and propoxur added to the wells. We allowed the cells to grow for 3-5 days and estimated the number of cells as described. Control cell wells contained only cells with $1 \mu 1 / \mathrm{mL}$ of DMSO. All treatment and control experiments repeated at least four replicates.

\section{Cell line number estimation}

The base method for cell estimation is the Mossman method, which uses 3-(4,5-dimethylthiazol-2-yl)-2,5-difenyltetrazolium bromide (MTT, tetrazolium, compound). MTT is a quantitative coloring for living cells and cell proliferation, and it is a known method for in vitro cytotoxicity which measures the active metabolism of the cells. In this coloring solution, dehydrogenase enzyme reduced the MTT and produced blue formazan.

The wells of 96-well plates containing invertebrate ( $\mathrm{Sf} 9)$ and vertebrate (L929) cell lines were incubated with $10 \mu$ MTT for $3 \mathrm{~h}$ at $36^{\circ} \mathrm{C}$ and $27^{\circ} \mathrm{C}$, respectively. After the blue formazan and cells settled out and the supernatant was removed, $100 \mu$ of DMSO was added to any well of 96-well plate, shaked for $15 \mathrm{~min}$ and then the absorbance of the solution read at $492 \mathrm{~nm}$ using ELISA reader [24].

\section{Statistical analysis}

The cytotoxicity trend lines of $N$. crispa essential oil and propoxur against invertebrate (Sf9) and vertebrate (L929) cell lines were estimated by Microsoft Excel version 2013. The trend lines were drawn by clicking on graph line distribution and selecting "add trendline" option using procedure described in previous studies [17-28].The equations and R-squared values of the cytotoxicity trend lines were also calculated by Microsoft Excel. IBM SPSS statistics data editor version 24 was used for any statistical analyses. Wilcoxon signed-rank test was used for comparing cytotoxicity of essential oil of $N$. crispa plant and propoxur between control and treatments, and cross treatments of $N$. crispa plant and propoxur. $\mathrm{p}<0.05$ was considered statistically significant.

\section{Results}

Cytotoxicity of $\boldsymbol{N}$. crispa essential oil and propoxur

Tables- 1 and 2 show the data of $N$. crispa essential oil and propoxur cytotoxicity against invertebrate (Sf9) and vertebrate (L929) cell lines, respectively. Figures-1 and 2 show the cytotoxicity of $N$. crispa essential oil and propoxur against invertebrate ( $\mathrm{Sf} 9$ ) and vertebrate (L929) cell lines, respectively. Figure-3 shows the cytotoxicity trend lines of $N$. crispa essential 
Table-1: Cytotoxicity of Nepeta crispa essential oil ( $\mathrm{ng} / \mu \mathrm{L})$ against invertebrate (Sf9) and vertebrate (L929) cell lines.

\begin{tabular}{|c|c|c|c|c|c|c|c|c|c|}
\hline Replicate & & $\mathbf{R}_{1}$ & $\mathbf{R}_{2}$ & $\mathbf{R}_{3}$ & $\mathbf{R}_{4}$ & $\mathbf{R}_{5}$ & $\mathbf{R}_{6}$ & $\mathbf{R}_{\mathbf{7}}$ & $\mathbf{R}_{8}$ \\
\hline \multicolumn{10}{|l|}{ Control } \\
\hline & Sf9 & 0.898 & 0.731 & 0.429 & 0.564 & - & - & - & - \\
\hline & L929 & 0.244 & 0.276 & 0.273 & 0.265 & 0.154 & 0.104 & 0.130 & 0.159 \\
\hline \multicolumn{10}{|l|}{ Treatment } \\
\hline \multicolumn{10}{|l|}{ Concentration } \\
\hline \multirow[t]{2}{*}{$10^{-10}$} & Sf9 & 0.769 & 0.561 & 0.865 & 0.732 & - & - & - & - \\
\hline & L929 & 0.594 & 0.556 & 0.578 & 0.278 & 0.858 & 0.862 & 0.935 & 0.873 \\
\hline \multirow[t]{2}{*}{$10^{-9}$} & Sf9 & 0.699 & 0.34 & 0.431 & 0.569 & - & - & - & - \\
\hline & L929 & 0.548 & 0.525 & 0.572 & 0.538 & 0.837 & 0.867 & 0.876 & - \\
\hline \multirow[t]{2}{*}{$10^{-8}$} & Sf9 & 0.692 & 0.986 & 0.593 & 0.496 & - & - & - & - \\
\hline & L929 & 0.554 & 0.545 & 0.538 & 0.580 & 0.813 & 0.827 & 0.865 & 0.837 \\
\hline \multirow[t]{2}{*}{$10^{-7}$} & Sf9 & 0.239 & 0.292 & 0.268 & 0.277 & - & - & - & - \\
\hline & L929 & 0.560 & 0.588 & 0.575 & 0.75 & 0.83 & 0.859 & 0.872 & 0.854 \\
\hline \multirow[t]{2}{*}{$10^{-6}$} & Sf9 & 0.279 & 0.322 & 0.301 & 0.269 & - & - & - & - \\
\hline & L929 & 0.578 & 0.588 & 0.583 & 0.842 & 0.861 & 0.893 & 0.865 & - \\
\hline \multirow[t]{2}{*}{$10^{-5}$} & Sf9 & 0.242 & 0.24 & 0.262 & 0.243 & - & - & - & - \\
\hline & L929 & 0.598 & 0.546 & 0.87 & 0.691 & 0.695 & - & - & - \\
\hline \multirow[t]{2}{*}{$10^{-4}$} & Sf9 & 0.192 & 0.217 & 0.269 & 0.235 & - & - & - & - \\
\hline & L929 & 0.861 & 0.909 & 0.101 & 0.878 & 0.723 & 0.699 & 0.707 & - \\
\hline \multirow[t]{2}{*}{$10^{-3}$} & Sf9 & 0.191 & 0.235 & 0.222 & 0.231 & - & - & - & - \\
\hline & L929 & 0.573 & 0.546 & 0.545 & 0.668 & - & - & - & - \\
\hline
\end{tabular}

Cell line of Sf9 derived from the ovary gland of the fall armyworm, Spodoptera frugiperda (Smith) (Lepidoptera: Noctuidae). Cell line of L929 derived from mouse fibroblast cells. $R=$ Replicate

Table-2: Cytotoxicity of propoxur ( $\mu \mathrm{g} / \mu \mathrm{L})$ against invertebrate (Sf9) and vertebrate (L929) cell lines.

\begin{tabular}{|c|c|c|c|c|c|c|c|c|c|}
\hline Replicate & & $\mathbf{R}_{1}$ & $\mathbf{R}_{\mathbf{2}}$ & $\mathbf{R}_{\mathbf{3}}$ & $\mathbf{R}_{\mathbf{4}}$ & $\mathbf{R}_{\mathbf{5}}$ & $\mathbf{R}_{6}$ & $\mathbf{R}_{\mathbf{7}}$ & $\mathbf{R}_{8}$ \\
\hline \multicolumn{10}{|l|}{ Control } \\
\hline & Sfg & 0.429 & 0.256 & 0.274 & 0.307 & - & - & - & - \\
\hline & L929 & 0.429 & 0.256 & 0.274 & 0.307 & 0.377 & 0.319 & 0.287 & 0.226 \\
\hline \multicolumn{10}{|l|}{ Treatment } \\
\hline \multicolumn{10}{|c|}{ Concentration } \\
\hline \multirow[t]{2}{*}{$10^{-10}$} & Sf9 & 0.402 & 0.254 & 0.27 & 0.249 & - & - & - & - \\
\hline & L929 & 0.402 & 0.254 & 0.27 & 0.249 & 0.213 & 0.238 & 0.243 & 0.208 \\
\hline \multirow[t]{2}{*}{$10^{-9}$} & Sf9 & 0.263 & 0.232 & 0.264 & 0.390 & - & - & - & - \\
\hline & L929 & 0.263 & 0.242 & 0.244 & 0.253 & 0.21 & 0.22 & 0.228 & 0.236 \\
\hline \multirow[t]{2}{*}{$10^{-8}$} & Sf9 & 0.267 & 0.257 & 0.25 & 0.258 & - & - & - & - \\
\hline & L929 & 0.255 & 0.257 & 0.25 & 0.245 & 0.183 & 0.215 & 0.221 & 0.206 \\
\hline \multirow[t]{2}{*}{$10^{-7}$} & Sf9 & 0.244 & 0.272 & 0.263 & 0.235 & - & - & - & - \\
\hline & L929 & 0.244 & 0.247 & 0.243 & 0.194 & 0.215 & 0.219 & - & - \\
\hline \multirow[t]{2}{*}{$10^{-6}$} & Sf9 & 0.275 & 0.225 & 0.264 & 0.236 & - & - & - & - \\
\hline & L929 & 0.243 & 0.225 & 0.23 & 0.237 & 0.183 & 0.211 & 0.217 & - \\
\hline \multirow[t]{2}{*}{$10^{-5}$} & Sf9 & 0.241 & 0.247 & 0.243 & 0.2437 & - & - & - & - \\
\hline & L929 & 0.238 & 0.229 & 0.225 & 0.223 & 0.2 & 0.199 & 0.226 & - \\
\hline \multirow[t]{2}{*}{$10^{-4}$} & Sf9 & 0.226 & 0.225 & 0.261 & 0.231 & - & - & - & - \\
\hline & L929 & 0.226 & 0.225 & 0.221 & 0.229 & 0.187 & 0.209 & 0.216 & - \\
\hline \multirow[t]{2}{*}{$10^{-3}$} & Sf9 & 0.226 & 0.219 & 0.221 & 0.222 & - & - & - & - \\
\hline & L929 & 0.212 & 0.225 & 0.219 & 0.211 & 0.215 & - & - & - \\
\hline
\end{tabular}

Cell line of Sf9 derived from the ovary gland of the fall armyworm, Spodoptera frugiperda (Smith) (Lepidoptera: Noctuidae). Cell line of L929 derived from mouse fibroblast cells. R=Replicate

oil $(\mathrm{ng} / \mu \mathrm{L})$ and propoxur $(\mu \mathrm{g} / \mu \mathrm{L})$ against invertebrate (Sf9) and vertebrate (L929) cell lines. Table-3 shows the results of descriptive analysis and Wilcoxon signed-rank test between control and treatments, treatments and cross treatments of cytotoxicity of essential oil of N. crispa plant, and propoxur against invertebrate (Sf9) and vertebrate (L929) cell lines.

The cytotoxicity of essential oil of $N$. crispa plant against invertebrate (Sf9) cell line was strongly increased with an intensive increasing slope in accordance with essential oil concentrations of $N$. crispa plant from $10^{-10}$ to $10^{-3} \mu \mathrm{g} / \mu \mathrm{L}$ (Figures-1a and 3), while the cytotoxicity of essential oil of $N$. crispa plant against vertebrate (L929) cell line was gradually decreased with a moderately increasing slope in accordance with essential oil concentrations of $N$. crispa plant from $10^{-10}$ to $10^{-3} \mu \mathrm{g} / \mu \mathrm{L}$ (Figures- $1 \mathrm{~b}$ and 3). Wilcoxon signed-rank test revealed significant differences between the treatments of $10^{-10}$ and $10^{-4}$ essential oil concentrations of $N$. crispa plant against vertebrate (L929) cell line with control $(p<0.05)$ (Table-3 and Figure-1b). Wilcoxon signedrank test did not show a significant difference between the treatment of $10^{-3}$ essential oil concentration of 


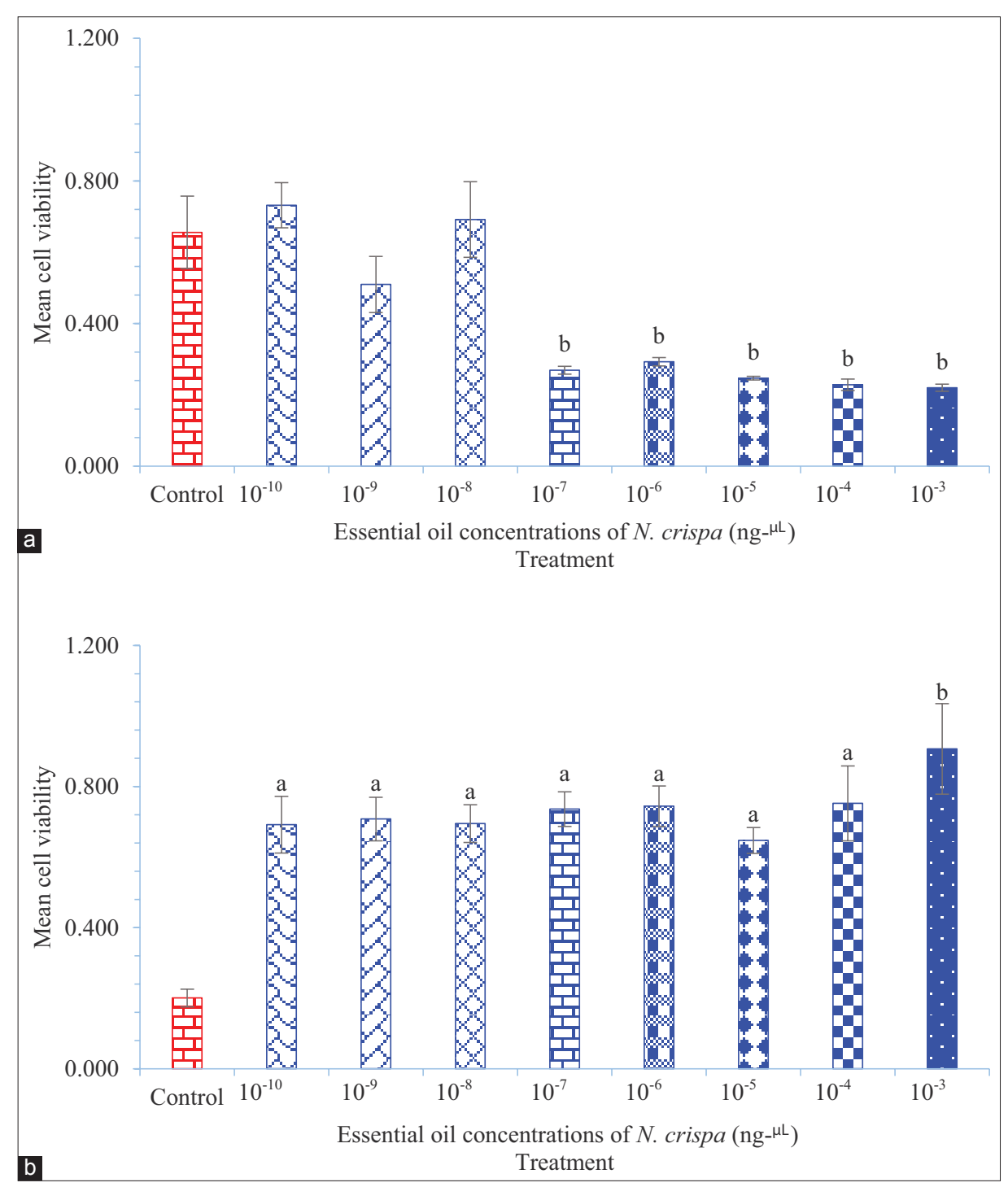

Figure-1: Cytotoxicity Nepeta crispa essential oil against invertebrate (Sf9) and vertebrate (L929) cell lines. (a) Essential oil of $N$. crispa plant against cell line of Sf9 and (b) essential oil of $N$. crispa plant against cell line of L929. Compared with control: (a) $p<0.05$ and (b) $p<0.001$. Cell line of Sf9 derived from the ovary gland of the fall armyworm, Spodoptera frugiperda (Smith) (Lepidoptera: Noctuidae). Cell line of L929 derived from mouse fibroblast cells.

N. crispa plant against vertebrate (L929) cell line with control $(\mathrm{p}=0.068)$ (Table-3), even though there was a significant difference at $\mathrm{p}<0.001$ level between the treatments of $10^{-3}$ essential oil concentration of $N$. crispa plant against vertebrate (L929) cell line with control (Figure-1b). Wilcoxon signed-rank test did not show significant differences between the treatments of $10^{-10}$ and $10^{-3}$ essential oil concentrations of $N$. crispa plant against invertebrate (Sf9) cell line with control ( $p>0.05$ ) (Table-2 and Figure-1a), even though there were significant differences at $p<0.001$ level between the treatments of $10^{-7}$ and $10^{-3}$ essential oil concentrations of $N$. crispa plant against cell line of Sf9 (Figure-1a).

The cytotoxicity of propoxur against invertebrate (Sf9) and vertebrate (L929) cell lines was gradually increased with a relatively low decreasing slope in accordance with propoxur concentrations from $10^{-10}$ to $10^{-3} \mu \mathrm{g} / \mu \mathrm{L}$ (Figures-2a, $\mathrm{b}$ and 3 ). Wilcoxon signed-rank test did not show significant differences between the treatments of $10^{-10}$ and $10^{-3}$ concentrations of propoxur against invertebrate ( $\mathrm{Sf} 9$ ) cell line with control ( $>>0.05)$ (Table-3 and Figure2a),even though there was a significant difference at $\mathrm{p}<0.001$ level between the treatments of $10^{-10}$ and $10^{-5}$ to $10^{-3}$ concentrations of propoxur against invertebrate ( $\mathrm{Sf} 9$ ) cell line (Figure-2a). There were also significant differences between the treatments of $10^{-10}$ and $10^{-3}$ concentrations of propoxur against vertebrate (L929) cell line with control $(p<0.05)$ (Table-3 and Figure-2b).

\section{Comparing of $\boldsymbol{N}$. crispa essential oil and propoxur cytotoxicity}

The cytotoxicity of essential oil of $N$. crispa plant against invertebrate (Sf9) cell line was strongly increased with an intensive increasing slope in accordance with essential oil concentrations of N. crispa plant, while the cytotoxicity of essential oil of $N$. crispa plant against vertebrate (L929) cell line was gradually decreased with a moderately increasing 


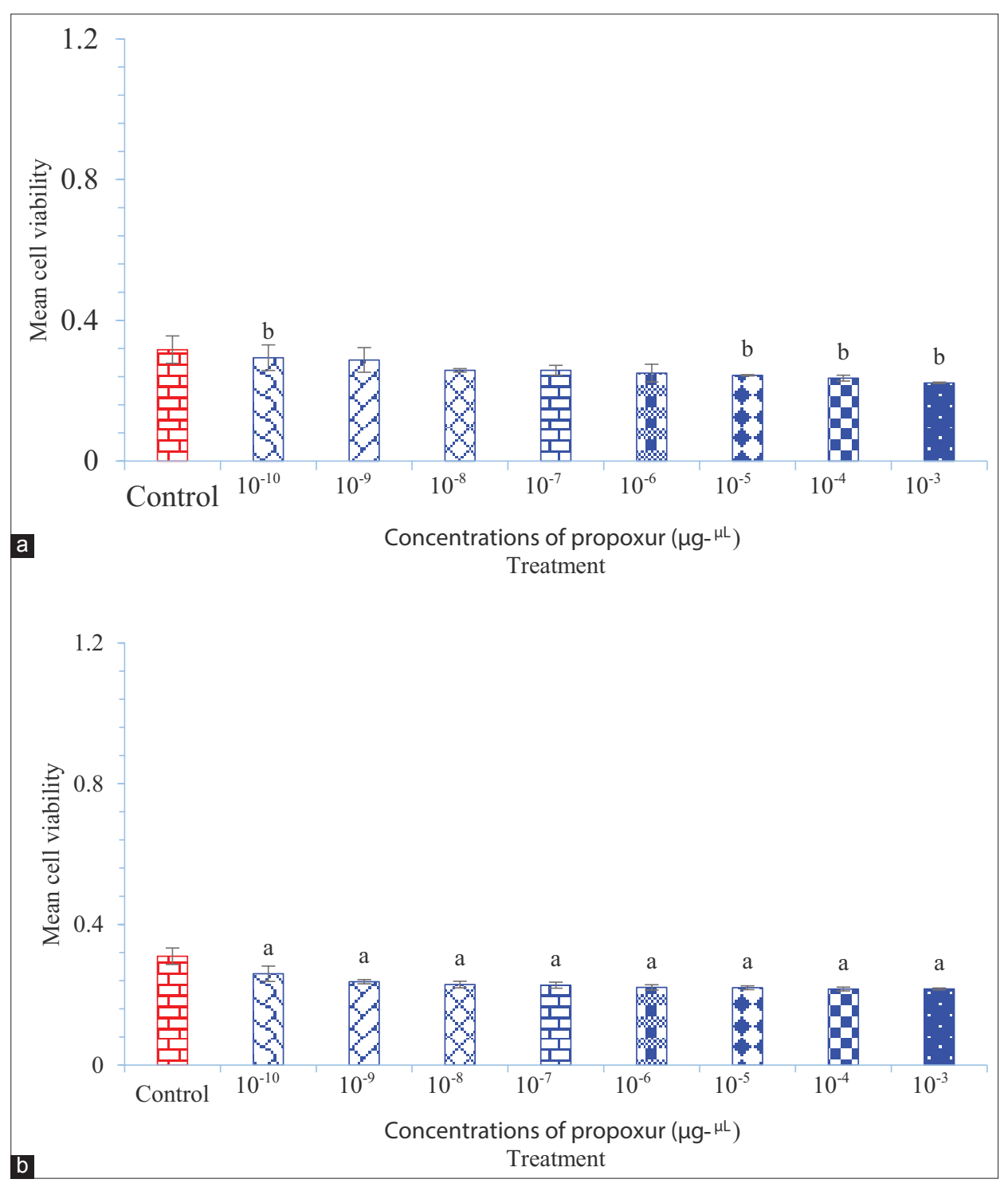

Figure-2: Cytotoxicity of propoxur against invertebrate (Sf9) and vertebrate (L929) cell lines. (a) Propoxur against cell line of Sf9 and (b) propoxur against cell line of L929. Compared with control: (a) $p<0.05$ and (b) $p<0.001$. Cell line of Sf9 derived from the ovary gland of the fall armyworm, Spodoptera frugiperda (Smith) (Lepidoptera: Noctuidae). Cell line of L929 derived from mouse fibroblast cells.

slope in accordance with essential oil concentrations of $N$. crispa plant. The cytotoxicity of propoxur against invertebrate (Sf9) and vertebrate (L929) cell lines was gradually increased with a relatively low decreasing slope in accordance with propoxur concentrations (Figure-3).

Wilcoxon signed-rank test did not show significant differences between separately treatments and cross treatments of $N$. crispa plant and propoxur concentrations against invertebrate ( $\mathrm{Sf} 9)$ and vertebrate (L929) cell lines, and invertebrate (Sf9) cell line, respectively $(\mathrm{p}>0.05)$, even though there were significant differences between cross treatments $\left(10^{-10}-10^{-4}\right)$ of $N$. crispa plant and propoxur concentrations against vertebrate (L929) cell line $(\mathrm{p}<0.05)$ (Table-3).

\section{Discussion}

Based on the results of the study, propoxur had negative effects on the viability of both invertebrate (Sf9) and vertebrate (L929) cell lines. These results confirm the reports of the previous studies that concluded insecticides decreased growth of the invertebrate and vertebrate cell lines [29,30]. Compared with the propoxur treatment experiments, the highest rate of cell viability was observed in the control group which did not receive any toxic agent.The viability of cell lines which were exposed to the different concentrations of propoxur was lower than control group and decreased with increasing concentrations of propoxur. The negative effects of propoxur on the viability of both invertebrate ( $\mathrm{Sf9}$ ) and vertebrate (L929) cell lines were also confirmed by Wilcoxon signed-rank test by observing significant differences between the treatments of $10^{-5}-10^{-3}$ and $10^{-8}-10^{-3}$ concentrations of propoxur with control group against the invertebrate (Sf9) and vertebrate (L929) cell lines, respectively, at $\mathrm{p}<0.05$ or $\mathrm{p}<0.001$ levels (Table- 3 ).

Unlike propoxur, essential oil of $N$. crispa plant did not have negative effects on the viability of vertebrate (L929) cell line. Compared with the control 
Available at www.veterinaryworld.org/Vol.12/November-2019/3.pdf

Table-3: Results of Wilcoxon signed-rank test between cytotoxicity of $N$. crispa essential oil and propoxur against invertebrate (Sf9) and vertebrate (L929) cell lines.

\begin{tabular}{|c|c|c|c|c|c|c|c|c|c|}
\hline \multicolumn{10}{|c|}{ Descriptive statistics } \\
\hline \multicolumn{5}{|c|}{ Essential oil of $\boldsymbol{N}$. crispa plant } & \multicolumn{5}{|c|}{ Propoxur } \\
\hline \multirow[t]{2}{*}{ Concentration } & Mean & $\begin{array}{l}\text { Standard } \\
\text { deviation }\end{array}$ & Mean & $\begin{array}{l}\text { Standard } \\
\text { deviation }\end{array}$ & Concentration & Mean & $\begin{array}{l}\text { Standard } \\
\text { deviation }\end{array}$ & Mean & $\begin{array}{l}\text { Standard } \\
\text { deviation }\end{array}$ \\
\hline & Sf9 & & L929 & & & Sf9 & & L929 & \\
\hline $\begin{array}{l}\text { Control } \\
\text { Treatment }\end{array}$ & 0.6555 & 0.2035 & 0.2006 & 0.0709 & $\begin{array}{l}\text { Control } \\
\text { Treatment }\end{array}$ & 0.3165 & 0.0779 & 0.3094 & 0.0660 \\
\hline $10^{-10}$ & 0.7318 & 0.1269 & 0.6918 & 0.2270 & $10^{-10}$ & 0.2938 & 0.0727 & 0.2596 & 0.0611 \\
\hline $10^{-9}$ & 0.5098 & 0.1574 & 0.7080 & 0.1748 & $10^{-9}$ & 0.2873 & 0.0701 & 0.2370 & 0.0173 \\
\hline $10^{-8}$ & 0.6918 & 0.2119 & 0.6949 & 0.1515 & $10^{-8}$ & 0.2580 & 0.0085 & 0.2290 & 0.0269 \\
\hline $10^{-7}$ & 0.2690 & 0.0223 & 0.7360 & 0.1391 & $10^{-7}$ & 0.2580 & 0.0198 & 0.2270 & 0.0212 \\
\hline $10^{-6}$ & 0.2928 & 0.0236 & 0.7443 & 0.1516 & $10^{-6}$ & 0.2500 & 0.0354 & 0.2209 & 0.0200 \\
\hline $10^{-5}$ & 0.2468 & 0.0102 & 0.6471 & 0.1039 & $10^{-5}$ & 0.2437 & 0.0031 & 0.2200 & 0.0148 \\
\hline $10^{-4}$ & 0.2283 & 0.0324 & 0.7522 & 0.3007 & $10^{-4}$ & 0.2358 & 0.0170 & 0.2161 & 0.0145 \\
\hline $10^{-3}$ & 0.2198 & 0.0199 & 0.9065 & 0.3632 & $10^{-3}$ & 0.2220 & 0.0036 & 0.2164 & 0.0057 \\
\hline
\end{tabular}

\section{Wilcoxon signed-rank test}

Analysis between treatments and control

\begin{tabular}{|c|c|c|c|c|c|c|c|c|c|}
\hline \multicolumn{6}{|c|}{ Essential oil of $N$. crispa plant } & \multicolumn{4}{|c|}{ Propoxur } \\
\hline & & \multicolumn{2}{|c|}{ Mean ranks } & \multirow[t]{2}{*}{$\mathbf{z}$} & \multirow{2}{*}{$\begin{array}{l}\text { p-value (two } \\
\text { tailed) }\end{array}$} & \multicolumn{2}{|c|}{ Mean ranks } & \multirow[t]{2}{*}{$\mathbf{z}$} & \multirow{2}{*}{$\begin{array}{c}\text { p-value } \\
\text { (two } \\
\text { tailed) }\end{array}$} \\
\hline & & Negative & Positive & & & Negative & Positive & & \\
\hline \multicolumn{10}{|l|}{$\overline{\text { Sf9 }}$} \\
\hline & $10^{-10}$ & 2.0 & 3.0 & $-0.365^{\mathrm{b}}$ & 0.715 & 2.5 & 0.001 & $-1.826^{c}$ & 0.068 \\
\hline & $10^{-9}$ & 3.5 & 1.5 & $-0.730^{c}$ & 0.465 & 2.3 & 3.0 & $-0.730^{c}$ & 0.465 \\
\hline & $10^{-8}$ & 2.0 & 3.0 & $-0.365^{c}$ & 0.715 & 3.0 & 1.0 & $-1.461^{\mathrm{c}}$ & 0.144 \\
\hline & $10^{-7}$ & 2.5 & 0.001 & $-1.826^{c}$ & 0.068 & 3.0 & 1.0 & $-1.461^{\mathrm{c}}$ & 0.144 \\
\hline & $10^{-6}$ & 2.5 & 0.001 & $-1.826^{c}$ & 0.068 & 3.0 & 1.0 & $-1.461^{\mathrm{c}}$ & 0.144 \\
\hline & $10^{-5}$ & 2.5 & 0.001 & $-1.826^{c}$ & 0.068 & 2.5 & 0.001 & $-1.826^{c}$ & 0.068 \\
\hline & $10^{-4}$ & 2.5 & 0.001 & $-1.826^{c}$ & 0.068 & 2.5 & 0.001 & $-1.826^{c}$ & 0.068 \\
\hline & $10^{-3}$ & 2.5 & 0.001 & $-1.826^{c}$ & 0.068 & 2.5 & 0.001 & $-1.826^{c}$ & 0.068 \\
\hline \multicolumn{10}{|l|}{ L929 } \\
\hline & $10^{-10}$ & 0.001 & 4.5 & $-2.521^{b}$ & 0.012 & 4.5 & 0.001 & $-2.521^{c}$ & 0.012 \\
\hline & $10^{-9}$ & 0.001 & 4.0 & $-2.366^{\mathrm{b}}$ & 0.018 & 5.0 & 1.0 & $-2.380^{\circ}$ & 0.017 \\
\hline & $10^{-8}$ & 0.001 & 4.5 & $-2.521^{b}$ & 0.012 & 5.0 & 1.0 & $-2.380^{c}$ & 0.017 \\
\hline & $10^{-7}$ & 0.001 & 4.5 & $-2.521^{b}$ & 0.012 & 3.5 & 0.001 & $-2.201^{c}$ & 0.028 \\
\hline & $10^{-6}$ & 0.001 & 4.0 & $-2.366^{b}$ & 0.018 & 4.0 & 0.001 & $-2.371^{\mathrm{c}}$ & 0.018 \\
\hline & $10^{-5}$ & 0.001 & 4.5 & $-2.521^{b}$ & 0.012 & 4.0 & 0.001 & $-2.366^{c}$ & 0.018 \\
\hline & $10^{-4}$ & 1.0 & 4.5 & $-2.197^{b}$ & 0.028 & 4.0 & 0.001 & $-2.366^{c}$ & 0.018 \\
\hline & $10^{-3}$ & 0.001 & 2.5 & $-1.826^{b}$ & 0.068 & 3.0 & 0.001 & $-2.023^{c}$ & 0.043 \\
\hline & & Sf9 & & & & L929 & & & \\
\hline \multicolumn{10}{|c|}{ Analysis between the treatments of essential oil of $N$. crispa plant and propoxur } \\
\hline $10^{-10}$ & $10^{-10}$ & 0.001 & 2.5 & $-1.826^{b}$ & 0.068 & 0.001 & 0.001 & $0.0001^{a}$ & 1.000 \\
\hline $10^{-9}$ & $10^{-9}$ & 3.0 & 2.0 & $-0.365^{c}$ & 0.715 & 1.0 & 2.5 & $-1.069^{b}$ & 0.285 \\
\hline $10^{-8}$ & $10^{-8}$ & 2.0 & 2.7 & $-1.095^{b}$ & 0.273 & 0.001 & 1.5 & $-1.342^{b}$ & 0.180 \\
\hline $10^{-7}$ & $10^{-7}$ & 2.5 & 0.001 & $-1.826^{c}$ & 0.068 & 0.001 & 2.0 & $-1.604^{b}$ & 0.109 \\
\hline $10^{-6}$ & $10^{-6}$ & 2.5 & 0.001 & $-1.826^{c}$ & 0.068 & 1.0 & 2.5 & $-1.069^{b}$ & 0.285 \\
\hline $10^{-5}$ & $10^{-5}$ & 2.5 & 0.001 & $-1.826^{c}$ & 0.068 & 0.001 & 2.5 & $-1.841^{\mathrm{b}}$ & 0.066 \\
\hline $10^{-4}$ & $10^{-4}$ & 3.0 & 1.0 & $-1.461^{\mathrm{c}}$ & 0.144 & 0.001 & 1.5 & $-1.342^{b}$ & 0.180 \\
\hline $10^{-3}$ & $10^{-3}$ & 2.5 & 0.001 & $-1.826^{c}$ & 0.068 & 2.0 & 2.7 & $-1.095^{b}$ & 0.273 \\
\hline \multicolumn{10}{|c|}{ Cross analysis between the treatments of essential oil of $N$. crispa plant and propoxur } \\
\hline $10^{-10}$ & $10^{-10}$ & 0.00 & 2.50 & $-1.826^{b}$ & 0.068 & 0.001 & 4.50 & $-2.521^{b}$ & 0.012 \\
\hline $10^{-9}$ & $10^{-9}$ & 0.00 & 2.50 & $-1.826^{b}$ & 0.068 & 0.001 & 4.00 & $-2.371^{b}$ & 0.018 \\
\hline $10^{-8}$ & $10^{-8}$ & 0.00 & 2.50 & $-1.826^{b}$ & 0.068 & 0.001 & 4.50 & $-2.524^{b}$ & 0.012 \\
\hline $10^{-7}$ & $10^{-7}$ & 1.50 & 2.83 & $-1.289^{b}$ & 0.197 & 0.001 & 3.50 & $-2.201^{b}$ & 0.028 \\
\hline $10^{-6}$ & $10^{-6}$ & 0.00 & 2.50 & $-1.826^{b}$ & 0.068 & 0.001 & 4.00 & $-2.366^{b}$ & 0.018 \\
\hline $10^{-5}$ & $10^{-5}$ & 2.00 & 3.00 & $-0.365^{b}$ & 0.715 & 0.001 & 4.00 & $-2.371^{b}$ & 0.018 \\
\hline $10^{-4}$ & $10^{-4}$ & 3.25 & 1.75 & $-0.552^{c}$ & 0.581 & 1.00 & 4.50 & $-2.197^{b}$ & 0.028 \\
\hline $10^{-3}$ & $10^{-3}$ & 4.00 & 2.00 & $-0.365^{b}$ & 0.715 & 0.001 & 2.50 & $-1.826^{b}$ & 0.068 \\
\hline
\end{tabular}

aThe sum of negative ranks equals the sum of positive ranks, bbased on negative ranks and cbased on positive ranks. The $p$-value of significant $(p<0.05)$ is shown in bold font style. Cell line of Sf9 derived from the ovary gland of the fall armyworm, Spodoptera frugiperda (Smith) (Lepidoptera: Noctuidae). Cell line of L929 derived from mouse fibroblast cells. R=Replicate. N. crispa: Nepeta crispa 


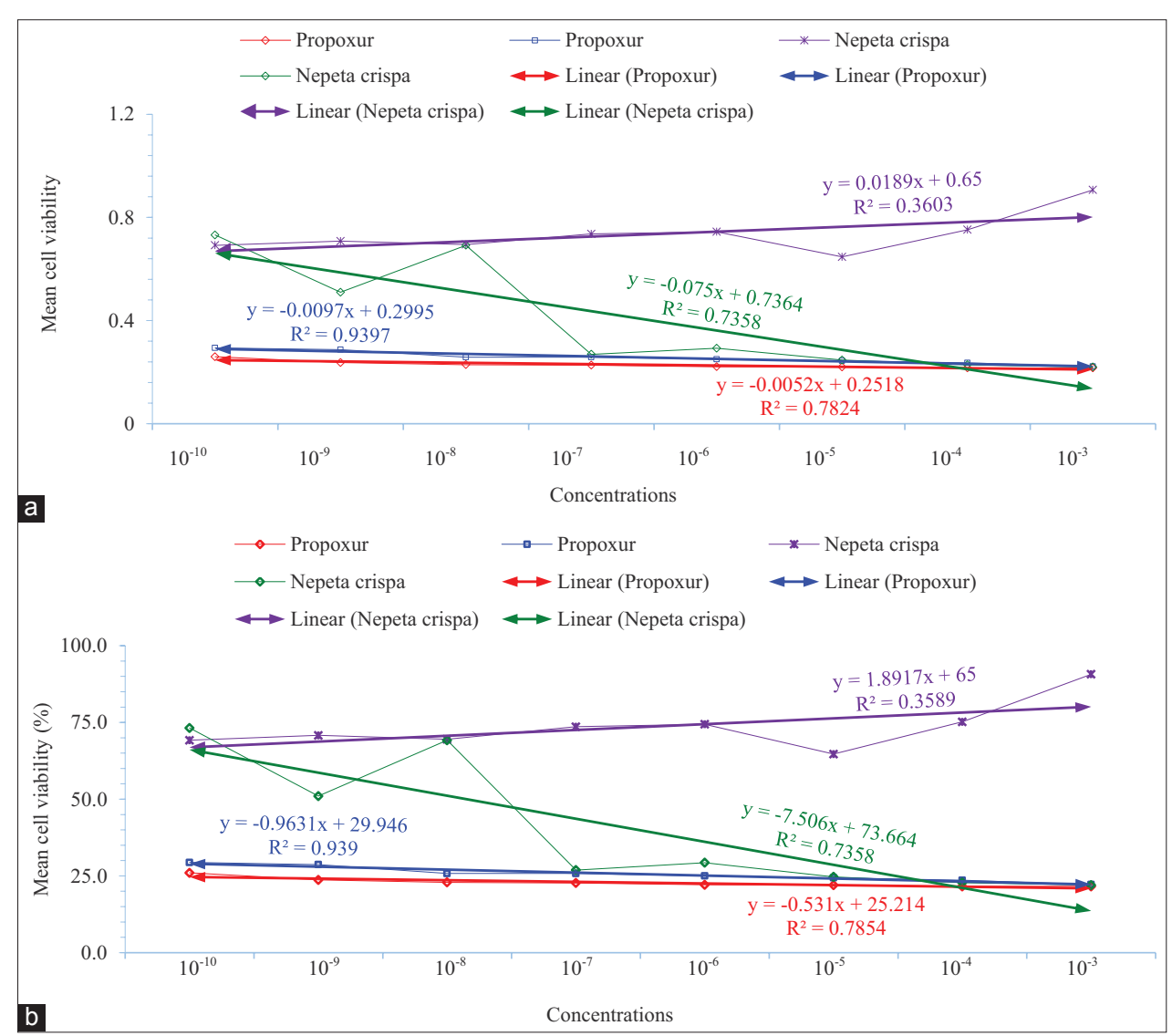

Figure-3: Cytotoxicity trend lines of Nepeta crispa essential oil ( $\mathrm{ng} / \mu \mathrm{L})$ and propoxur $(\mu \mathrm{g} / \mu \mathrm{L})$ against invertebrate (Sf9) and vertebrate (L929) cell lines. (a) Normal data and (b) percentage. The trend lines were drawn by clicking on graph line distribution and selecting "add trendline" option. Cell line of Sf9 derived from the ovary gland of the fall armyworm, Spodoptera frugiperda (Smith) (Lepidoptera: Noctuidae). Cell line of L929 derived from mouse fibroblast cells.

group, the highest rate of cell viability was observed in the experiment treatments which were treated with essential oil of N. crispa plant. The viability of vertebrate (L929) cell line which was exposed to different essential oil concentrations of $N$. crispa plant was higher than control group and increased with increasing essential oil concentrations of $N$. crispa plant. The boosting effects of experiments of $N$. crispa plant on the viability of vertebrate (L929) cell line were also confirmed by Wilcoxon signed-rank test by observing significant differences between the treatments of $10^{-10}$ and $10^{-3}$ essential oil concentrations of $N$. crispa plant with propoxur treatments of $10^{-10}-10^{-3}$ concentrations and control group against the vertebrate (L929) cell line at $p<0.05$ or $p<0.001$ levels. In addition to some previous benefits of the natural products deriving from natural plants $[31,32]$, this boosting effects of essential oil of $N$. crispa plant on the viability of cell line of vertebrates may be considered as the new benefits of the products deriving from natural plants.

Like propoxur, essential oil of $N$. crispa plant had negative effects on the viability of invertebrate (Sf9) cell lines with the differences that the products deriving from natural plants possessing of readily biodegradable and environmentally friendly derivatives, hydrolyzing rapidly in nature, and nearly having no destructive effects on environment, humans, or the mammals $[1,2]$. In addition, the application of essential oil concentrations of $N$. crispa plant (ng/ $\mu \mathrm{L})$ was 1000 folds lower than concentrations of propoxur $(\mu \mathrm{g} / \mu \mathrm{L})$. The viability of invertebrate (Sf9) cell lines which were exposed to essential oil concentrations of $10^{-9}$ and $10^{-7}-10^{-3} \mathrm{~N}$. crispa plant was lower than control group and decreased with increasing essential oil concentrations of $N$. crispa plant.

The negative effects of essential oil of $N$. crispa plant on the viability of invertebrate ( $\mathrm{Sf} 9$ ) cell lines were also confirmed by Wilcoxon signed-rank test by observing a significant difference between the treatments of $10^{-7}$ and $10^{-3}$ essential oil concentrations of $N$. crispa plant with control group against the invertebrate (Sf9) cell lines at $p<0.001$ level. In addition to that, the food chain and ecosystem contamination with pesticides, non-target organism extinction, insecticide resistance of insects, mutation, and pollution of water and soil have been critical problems using pesticides in the past decades. However, with the application of the products deriving from natural plants, there is no concern about their potential side effects such as toxicity to non-target organisms, residues of pesticides, depletion of ozone layer, environmental pollution, and direct toxicity to users. We will not encounter probably some psychotic disorders, neurological diseases and fatigue of muscles or cancers, and face up to severe insecticide effects on performance of vertebrate reproductive system [2,9-12]. Some studies 
did not encounter a substantial problem of insecticide resistance in arthropods of the vectors of diseases and agricultural pests [7,13-19].

\section{Conclusion}

Based on the results of the study, propoxur had negative effects on the viability of both invertebrate and vertebrate cell lines. Unlike propoxur, essential oil of $N$. crispa plant did not have negative effects on the viability of vertebrate cell line. The viability of vertebrate cell line was increased with increasing essential oil concentrations of $N$. crispa plant. This boosting effect of $N$. crispa plant on the viability of vertebrate cell line may be considered as the new benefits of the products deriving from natural plants.

\section{Authors' Contributions}

$\mathrm{AS}$ and $\mathrm{AZ}$ planned the project. $\mathrm{MB}$ and $\mathrm{HN}$ conducted the experimental laboratory work and analyzed the data. SS assisted in analyzing of experimental data. AS and HN wrote the manuscript. AS supervised the project. All authors discussed the results and implications and commented on the manuscript at all stages. All authors read and approved the final manuscript.

\section{Acknowledgments}

We are thankful to Moshkfam Fars Company, Shiraz, Iran, for supplying propoxur insecticide. We also acknowledge the help of Mr. Kheiri for providing plant and other assistance during the research. This study forms part of Mitra Boroomand's M.Sc. thesis in Medical Entomology and Vector Control in the Department of Medical Entomology, School of Medicine, which was supported financially by the Research Deputy of Hamadan University of Medical Sciences, Iran (Grant no. 9605033004).

\section{Competing Interests} interests.

The authors declare that they have no competing

\section{Publisher's Note}

Veterinary World remains neutral with regard to jurisdictional claims in published institutional affiliation.

\section{References}

1. Prabhu, K., Murugan, K., Nareshkumar, A., Ramasubramanian, N. and Bragadeeswaran, S. (2011) Larvicidal and repellent potential of Moringa oleifera against malarial vector, Anopheles stephensi Liston (Insecta: Diptera: Culicidae). Asian Pac. J. Trop. Biomed., 1(2): 124-129.

2. Khani, A. and Asghari, J. (2012) Insecticide activity of essential oils of Mentha longifolia, Pulicaria gnaphalodes and Achillea wilhelmsii against two stored product pests, the flour beetle, Tribolium castaneum, and the cowpea weevil, Callosobruchus maculatus. J. Insect Sci., 12(1): 73.

3. Dunphy, B.M., Norris, E.J., Coats, J.R., Gross, A.D., Bartholomay, L. and Bessette, S. (2015) Comparison of the insecticidal characteristics of commercially available plant essential oils against Aedes aegypti and Anopheles gambiae
(Diptera: Culicidae). J. Med. Entomol., 52(5): 993-1002.

4. Rezaei, M. and Moharramipour, S. (2019) Efficacy of Dayabon, a botanical pesticide, on different life stages of Myzus persicae and its biological control agent, Aphidius matricariae. J. Crop Prod., 8(1): 1-10.

5. Rezaei, M., Khaghani, R. and Moharramipour, S. (2019) Insecticidal activity of Artemisia sieberi, Eucalyptus camaldulensis, Thymus persicus and Eruca sativa oils against German cockroach, Blattella germanica (L.). J. Asia Pac. Entomol., In Press.

6. Pepa, T.D., Elshafie, H.S., Capasso, R., De Feo, V., Camele, I., Nazzaro, F., Scognamiglio, M.R. and Caputo, L. (2019) Antimicrobial and phytotoxic activity of Origanum heracleoticum and $O$. majorana essential oils growing in Cilento (Southern Italy). Molecules, 24(14): E2576.

7. Nasirian, H. and Salehzadeh, A. (2019) Control of cockroaches (Blattaria) in sewers: A practical approach systematic review. J. Med. Entomol., 56(1): 181-191.

8. Perczak, A., Jus, K., Gwiazdowska, D., Marchwinska, K. and Waskiewicz, A. (2019) The efficiency of deoxynivalenol degradation by essential oils under in vitro conditions. Foods, 8(9): E403.

9. Bhatia, R., Shiau, R., Petreas, M., Weintraub, J.M., Farhang, L. and Eskenazi, B. (2004) Organochlorine pesticides and male genital anomalies in the child health and development studies. Environ. Health Perspect., 113(2): 220-224.

10. Milton, M., Ambrose, K., Abraham, C., Charles, N. and Kiriamiti，K. (2011) Dichlorodiphenyl trichloroethane (DDT) and its observed effects on body functions in vertebrates. East Afr. J. Public Health, 8(4): 277-279.

11. Alavanja, M.C. and Bonner, M.R. (2012) Occupational pesticide exposures and cancer risk: A review. J. Toxicol. Environ. Health B, 15(4): 238-263.

12. Menegaux, F., Baruchel, A., Lescoeur, B., Nelken, B., Clavel, J. and Leverger, G. (2006) Household exposure to pesticides and risk of childhood acute leukaemia. Occup. Environ. Med., 63(2): 131-134.

13. Nasirian, H. (2010) An overview of German cockroach, Blattella germanica, studies conducted in Iran. Pak. J. Biol. Sci., 13(22): 1077-1084

14. Nasirian, H. (2016) New aspects about Supella longipalpa (Blattaria: Blattellidae). Asian Pac. J. Trop. Biomed., 6(12): 1065-1075.

15. Nazari, M., Motlagh, B.A. and Nasirian, H. (2016) Toxicity of cypermethrin and chlorpyrifos against German cockroach [Blattella germanica (Blattaria: Blattellidae)] strains from Hamadan, Iran. Pak. J. Biol. Sci., 19(6): 259-264.

16. Davari, B., Hassanvand, A., Nasirian, H., Ghiasian, S., Salehzadeh, A. and Nazari, M. (2017) Comparison of cockroach fungal contamination in the clinical and non-clinical environments from Iran. J. Entomol. Acarol. Res., 49(2): 109-115.

17. Nasirian, H. (2017) Contamination of cockroaches (Insecta: Blattaria) to medically fungi: A systematic review and meta-analysis. J. Mycol. Med., 27(4): 427-448.

18. Veni, T., Pushpanathan, T. and Mohanraj, J. (2017) Larvicidal and ovicidal activity of Terminalia chebula Retz. (Family: Combretaceae) medicinal plant extracts against Anopheles stephensi, Aedes aegypti and Culex quinquefasciatus. J. Parasit. Dis., 41(3): 693-702.

19. Davari, B., Kashani, S., Nasirian, H., Nazari, M. and Salehzadeh, A. (2018) The efficacy of MaxForce and Avion gel baits containing fipronil, clothianidin and indoxacarb against the German cockroach (Blattella germanica). Entomol. Res., 48(6): 459-465.

20. Asgarpanah, J., Sarabian, S. and Ziarati, P. (2014) Essential oil of Nepeta genus (Lamiaceae) from Iran: A review. J. Essent. Oil Res., 26(1): 1-12.

21. Sonboli, A., Salehi, P. and Yousefzadi, M. (2004) Antimicrobial activity and chemical composition of the essential oil of Nepeta crispa Willd. from Iran. Z. Naturforsch., 59(9-10): 653-656. 
22. Zahirnia, A., Boroomand, M., Nasirian, H., SoleimaniAsl, S., Salehzadeh, A. and Dastan, D. (2019) The cytotoxicity of malathion and essential oil of Nepeta crispa (lamiales: lamiaceae) against vertebrate and invertebrate cell lines. Pan Afr. Med. J., 33: 285.

23. Salehzadeh, A., Jabbar, A., Jennens, L., Ley, S.V., Annadurai, R.S., Adams, R. and Strang, R.H.C. (2002) The effects of phytochemical pesticides on the growth of cultured invertebrate and vertebrate cells. Pest Manage. Sci., 58(3): 268-276.

24. Berridge, M.V., Tan, A.S., McCoy, K.D. and Wang, R. (1996) The biochemical and cellular basis of cell proliferation assays that use tetrazolium salts. Biochemica, 4(1): 14-19.

25. Nasirian, H. (2017) Infestation of cockroaches (Insecta: Blattaria) in the human dwelling environments: A systematic review and meta-analysis. Acta Trop., 167: 86-98.

26. Nasirian, H. (2019) Recent cockroach bacterial contamination trend in the human dwelling environments: A systematic review and meta-analysis. Bangladesh J. Med. Sci., 18(3): 540-545.

27. Nasirian, H. (2019) Crimean-Congo hemorrhagic fever (CCHF) seroprevalence: A systematic review and meta-analysis. Acta Trop., 196: 102-120.

28. Nasirian, H. and Salehzadeh, A. (2019) Effect of seasonality on the population density of wetland aquatic insects: A case study of the Hawr Al Azim and Shadegan wetlands, Iran. Vet. World, 12(4): 584-592.

29. Masoud, L., Vijayasarathy, C., Fernandez-Cabezudo, M., Petroianu, G. and Saleh, A. (2003) Effect of malathion on apoptosis of murine L929 fibroblasts: A possible mechanism for toxicity in low dose exposure. Toxicology, 185(1-2): 89-102.

30. Saleh, M., Hajjar, J. and Rahmo, A. (2013) Effect of selected insecticides on Sf9 insect cell line. Leban. Sci. J., 14(2): 115

31. Gharbani, P. and Javazi, H. (2015) The antioxidant, general toxicity and insecticidal activities of Nepeta scrophularioides Rech. f. extracts in different developmental stages. Pak. J. Pharm. Sci., 28(5): 1905-1609.

32. Tak, J.H., Jovel, E. and Isman, M.B. (2016) Comparative and synergistic activity of Rosmarinus officinalis L. essential oil constituents against the larvae and an ovarian cell line of the cabbage looper, Trichoplusia ni (Lepidoptera: Noctuidae). Pest Manage. Sci., 72(3): 474-480.

\section{$* * * * * * * *$}

